\title{
Učna okolja
}

Bodite pozorni na priložnosti, ki jih imate zato, da se kaj naučite! Vaše izobraževanje bo preveč skromno, če se boste zanašali samo na organizirane formalne programe: tečaje, seminarje, predavanja itd. Okrog vas je še veliko drugih možnosti za učenje. So ljudje z znanjem, ki ga vi še nimate, stvari, ki se odvijajo pred vašimi očmi in jih lahko opazujete, kopiči se literatura za branje, potujete in ste polni novih vtisov. Nemščino bi se najbolje in najhitreje naučili $v$ Nemčiji, tamkajšnjem učnem okolju, ker ne bi bili odvisni samo od tečaja, ampak bi vas na učenje jezika navajalo celotno okolje.

Učna okolja omogočajo kompleksno učenje. Namerno bi jih morali iskati in izbirati ter med seboj povezovati (če imamo pred očmi bolj dolgoročne učne cilje). Mentor lahko veliko pomaga pri odkrivanju izobraževalne možnosti ali učnih okolij v našem vsakdanjem življenju.

Kot vse ostalo po svetu se tudi vzgoja in izobraževanje soočata z velikimi spremembami. Ǔna okolja spadajo med pogosto omenjane nove pojave (learning environments). Tradicionalno smo poznali samo šolo kot učno okolje, danes govorimo v množini: učna okolja. Človek je izpostavljen več različnim učnim okoljem, saj se ljudje izobražujemo y zelo različnih situacijah vsakdanjega življenja. Brez te raznolikosti v učenju ljudi vseživljenjskega izobraževanja sploh ne bi bilo.

\section{Kaj je učno okolje?}

Vsega znanja nam eno samo učno okolje ne more dati. Pomembno je, da se učimo v več učnih okoljih, da bi dosegli pričakovano znanje: o temi se pogovarjamo v družini, ogledujemo si stvari v muzeju, srečamo se strokovnjakom, ki to že obvlada in ga opazujemo, itd. Šele tako si ustvarimo neko celovitejšo podobo znanja.

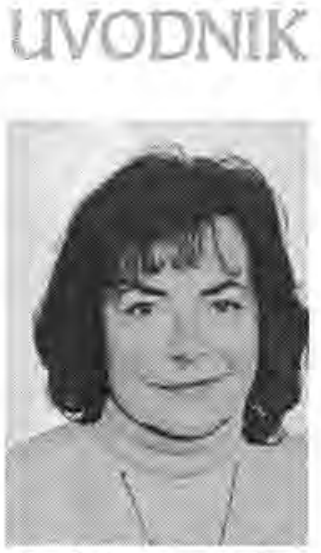

Prof. dr. Ana Krajnc
Uếno okolje je določena življenjska situacija ali določene zivljenjske okoliščine, $v$ katerih se znajde nek človek in ki omogočajo dovolj trajno in zgoščeno učenje, $s$ čimer človek uresničuje določene vzgojne cilje. To praviloma niso enkratne situacije, ampak okoliščine, $v$ katere lahko človek večkrat vstopi, se v njih znajde ali jih namerno poišče. S tem ne zanikamo, da so lahko tudi doživetja $v$ enem samem dogodku napravila tolikšen vis na človeka, da se je pri tem veliko naučil. Učno okolje, ki mu je bil človek izpostavljen samo enkrat in je napravilo nanj velik vtis, je navadno samo dodatek $k$ tistemu, kar je nekdo že prej znal. Ko smo nekemu novemu učnemu okolju le enkrat izpostavljeni, nam leto prejšnje znanje poveže, ga dopolni in spravi $\checkmark$ neko končno podobo. Za pridobivanje novih znanj (veščin, informacij) in razvijanje sposobnosti ter lastnosti ljudi je potrebno sodelovanje v trajnejših učnih okoljih. Pogovori s partnerjem se večkrat ponavljajo, preden sprejmemo nova stališča, angleško govorico med bivanjem $v$ Angliji večkrat poslušamo, da bi bili sposobni tudi sami pravilno uporabljati in izgovarjati tuje besede, itd.

Pojav učnih okolij bomo bolje pojasnili, če navedemo nekaj primerov. Učno okolje so lahko sprehodi $v$ naravo, razgovori s sorodnico, potovanje, pomoč prijateljici v času bolezni, življenje s partnerjem, nakupovanje, delo za preživetje, obiskovanje galerije, urejanje stanovanja in sodelovanje z obrtniki itd. Naštevanja ne bi mogli nikoli povsem izčrpati. Vsaka življenjska situacija lahko pod določenimi pogoji postane učno okolje. Imeti mora določene dodatne lastnosti: nuditi mora spoznavne možnosti, 
zavestno mora biti povezana z učnim ciljem. Oseba naj bi se zavestno trudila, da se v danih razmerah nekaj nauči (opazi, si zapomni, razume, začuti, sprejme), in pred seboj naj bi imela jasen cilj, kaj se hoče naučiti. Iz običajnega potovanja lahko bodisi za razvedrilo ali zaradi zaslužka naredimo učno okolje, če si potovanje. primerno strukturiramo tudi z vidika učenja. Arhitekt ima na primer priložnost, da potuje čez Evropo, od Sredozemlja do skandinavskih držav. Za potovanje si postavi poseben učni cilj, da bo opazoval in spoznaval tradicionalno ljudsko arhitekturo držav, skozi katere bo potoval. Izdela si podrobnejši načrt, kaj ga bo posebej zanimalo, $n p r$. nagib strehe, vrste kritine, ureditev okolice hiš, razčlenjenost hiš in še kaj. Tako je običajno potovanje postalo učno okolje.

Tudi druge življenjske situacije in okoliščne postanejo učna okolja, ko so izpolnjeni določeni pogoji: postavljen učni cilj in določene, zavestno izbrane poti za izobraževanje in spremljanje (evalvacijo) učenja. Če še naprej spremljamo omenjeni primer arhitekta, ugotavljamo, da si bo lahko za spoznavanje pokrajinske arhitekture izbral opazovanje z vlaka, obiske etnografskih muzejev v večjih mestih ali pa bo slikal posamezne značilne stavbe, jih pozneje primerjal in znanje dodatno poglobil s študijem literature. Učno okolje je možno uporabljati na različne načine in izbirati med več potmi. Učeči se navadno odloči za najbolj privlačno in z vidika učenja tudi obetavno pot.

Preselimo se $v$ drugo učno okolje! Nekdo zavzdihne in toži nad tem, kako mučna in dolga je bila bolezen prijateljice, istočasno pa nam pove, da se je ob tem veliko naučil. Ko bi moral drugič kaj podobnega obvladovati, bi se počutil povsem kompetentnega in bi se glede bolezni odločal brez strahu. Spoznal je na primer, kakšni so bolezenski znaki, kaj so glavna zdravila za to bolezen, stranske učinke zdravil, ve, kakšen je potek bolezni, pozna reakcije okolja na tako bolezensko stanje itd. Ker je bil ob bolezni prijateljice čustveno prizadet, je vse našteto spoznaval zelo zavzeto in pod vplivom močnih čustev. Se nam zdi $v$ učnih okoljih pridobljeno znanje nepomembno, ker nima formalnega potrdila? Izobraževanje $v$ učnih okoljih je vgrajeno $v$ življenje, prežeto $z$ raznimi čustvi, resničnimi riziki in podvrženo posledicam, če se do pravega znanja ne pride. To je izobraževanje "zares". Izobraževanje in življenje se v učnih okoljih najtesneje spojita.

Učna okolja so zelo osebno obarvana. Porajajo jih odnosi z ljudmi, razmere, v katerih nekdo živi, osebne potrebe in potrebe najbližjih, javni dogodki, družbene spremembe in celotno utripanje okolja. Kombinacija učnih okolij in možnosti je pri vsaki osebi drugačna, pa čeprav živi več ljudi (npr, družina) v navidezno enakem okolju. Ljudi med seboj ločijo doživetja, razlikujejo se po tem, čemu dajejo prednost, na kaj so pozornejši, kaj imajo raje in kaj jih odbija. Tako se učna okolja neke osebe postopoma strukturirajo in razlikujejo od učnih okolij druge osebe.

Ljudje so navadno še vedno premalo pozorni na potencialna učna okolja. Zato razne priložnosti za izobraževanje izpustijo, jih spregledajo, čeprav bi se $v$ njih lahko veliko naučili. Pomembna je vloga mentorja, da opozarja na učna okolja, poudari ali razmeji razne življenjske situacije neke osebe in jo navede na to, da izkoristi priložnost in se na primer pri svojem delu, prijateljevanju, potovanju, zdravljenju in podobno tudi nekaj od potrebnega nauči. V strokovni literaturi govorijo o mentorjevem krmiljenju (coaching) učeče se osebe. Mentor namesto študenta razmisli, katera bi bila optimalna situacija za učenje, kaj bi se lahko naučili že tam, kjer živijo ali delajo.

Kaj lahko pospeši, da se običajne življenjske razmere spreminjajo $v$ učna okolja? Najpomembnejša učna okolja so povezana z delom osebe. Č nekdo dolgo opravlja isto delo na istem mestu, se možnosti za učenje izčrpajo. Zelo pomembno je spreminjanje delovnega okolja. Staro delovno okolje oseba preveč pozna, da bi še nudilo možnosti za učenje. V informacijski družbi 
upada število zaposlitev za nedoločen čas in narašča število pogodbenih del za omejen čas. Vsakokrat, ko človek menja svoje delomo okolje, je izpostavljen novim vtisom in okolišcine ga prisilijo, da se spet zgoščeno uči. Če ne menja delovnega okolja, v svojem razvoju zakrni, saj se visi ponavljajo in že dolgo ni bil izpostavljen nobenim novim razmeram.

$\mathrm{Za}$ doseganje dolgoročnejših izobraževalnih ciljev sta potrebna povezovanje in koordinacija različnih učnih okolij. Poleg dela so pomembne ponavljajoče se situacije doma. Čustveno podprti odnosi med domačimi in dogodki v družini učenje ovirajo ali pa ga pospešujejo. Razmere in odnosi, prežeti s strahom in drugimi negativnimi čustvi, učenje blokirajo. Nasprotno pa pozitiven čustveni naboj požene izobraževanje in razmere zlije $v$ novo uěno okolje.

Poleg tega, da mentor navaja učenca na razna učna okolja v obstoječih razmerah, se lahko odloči, da bo izobraževanje podkrepil s "podtikanjem" novih učnih okolij. Učencu svetuje, naj se ponovno sreča z znancem in ima pred očmi, kaj bi rad spoznal, lahko mu svetuje, naj tudi sam sodeluje pri prenovi hiše, naroči mu, naj gre na razstavo in je pozoren na naštete stvari, svetuje mu lahko, naj se začne bolj pogosto družiti z nekom od znancev itd.

Tako za krmiljenje učenca $v$ raznih učnih okoljih kot tudi pri spodbujanju in svetovanju o novih učnih okoljih, mentor potrebuje jasno sliko o zivljenjskih razmerah in napredovanju pri izobraževanju. Nasveti bodo ustreznejši, če bodo izhajali iz sprotnega vrednotenja naučenega. $\mathrm{Ob}$ izdatni mentorjevi vlogi se učinek učnih okolij poveča, vplivi se med seboj povežejo, večata se učni uspeh in zadovoljstvo učencev.

Učna okolja so naravne življenjske situacijje. A. Tough na osnovi svojih študij opredeli, da se odrasli samo do 20 odstotkov izobražujejo po formalni poti, vse drugo je neformalno izobraževanje kot podlaga za vseživljenjsko učenje. Zato se učenec pogosto sploh ne zaveda več, da se uči, ker ga vsega prevzame dejansko do- gajanje; občasno izgubi kontrolo nad svojim učenjem in učnim okoljem, ker se bolj posveti dogodkom in osebam kot učenju. Čez čas se zamisli, kaj se je sploh naučil, kaj mu še manjka in ali lahko znanje že uporablja. Če ni zadovoljen, išče nova učna okolja (novega prijatelja, bolj pogoste stike s partnerjem, menjavo dela) in svoje izobraževanje pospeši.

Učno okolje ni monolitno izobraževanje samo po eni poti, kot je šolski pouk. V učnih okoljih delujejo na pridobivanje znanja šlevilni vplivi. Vse, kar $k$ neki življenjski situaciji spada, pripomore $k$ znanju. Izobraževanje postane del življenja.

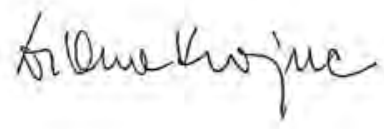

